Portland State University

PDXScholar

$5-22-2020$

\title{
Urban Hostility: CPTED, Hostile Architecture, and the Erasure of Democratic Public Space
}

Matthew M. Carr

Portland State University

Follow this and additional works at: https://pdxscholar.library.pdx.edu/honorstheses

Part of the Architecture Commons

Let us know how access to this document benefits you.

Recommended Citation

Carr, Matthew M., "Urban Hostility: CPTED, Hostile Architecture, and the Erasure of Democratic Public Space" (2020). University Honors Theses. Paper 892.

https://doi.org/10.15760/honors.913

This Thesis is brought to you for free and open access. It has been accepted for inclusion in University Honors Theses by an authorized administrator of PDXScholar. Please contact us if we can make this document more accessible: pdxscholar@pdx.edu. 


\section{Urban Hostility:}

CPTED, Hostile Architecture, and the Erasure of Democratic Public Space

By

\section{Matthew Carr}

An undergraduate thesis submitted in partial fulfillment of the

Requirements for the degree of
Bachelor of Science
In
University Honors
And
Architecture

Architecture

Thesis Advisor

Todd Ferry

Portland State University 


\begin{abstract}
$\underline{\text { Abstract }}$
Free and open public space is essential to the health of urban living. In theory, it is purely neutral, acting as a social equalizer providing those of all backgrounds space to co-exist within the confines of the built environment. However, truly democratic public space has consistently been threatened and reduced in cities, affecting none more heavily than marginalized and impoverished populations. The creation of the Crime Prevention Through Environmental Design agenda gave birth to hostile architecture, a detrimental form of urban exclusionism. By using hostile design typologies, cities can render public spaces unusable to undesirable citizens, and erase images of poverty, social decay and public disorder resulting in upper-class homogeneity. The ways in which CPTED and hostile architecture have led to the alarming erasure of free public space will be addressed, and consequences this has upon marginalized populations will be portrayed.
\end{abstract}




\section{$\underline{\text { Introduction }}$}

Free and open public space is essential to the health of urban living. In theory, it is purely neutral, acting as a social equalizer providing those of all backgrounds space to co-exist within the confines of the built environment. However, truly democratic public space has consistently been threatened and reduced in cities, affecting none more heavily than marginalized and impoverished populations. The creation of Oscar Newman's Defensible Space Theory in conjunction with criminologist C. Ray. Jeffrey's Crime Prevention Through Environmental Design resulted in the Crime Prevention through Environmental Design agenda (CPTED), demonstrating the ways in which physical environments play a critical role in crime prevention. CPTED gave birth to a form of urban exclusionism hinging on identifying users and legitimate or illegitimate. A consistent failure to recognize that identifying users in this way is inherently a value based process that can be undermined, has led to the abuse of CPTED guidelines and the creation of Hostile Architecture. Hostile devices are incredibly effective at perpetrating urban exclusionism through rendering public spaces unusable to certain users. By removing unwanted citizens from public spaces, cities can erase images of poverty, social decay and public disorder to attract commerce. This endangers the very nature of diversity in urban environments and brings into question whether public spaces are truly free and democratic.

Through an analysis of CPTED and hostile architecture, I will outline the ways in which hostile design tactics have targeted marginalized populations and led to the restriction of free public space while cultivating homogeneous cities. 


\section{CPTED and the Modern Origins of Hostile Architecture}

\section{Introduction}

To fully dissect hostile architecture, and recognize why it has been a mainstay in urban cores for decades, it is imperative to examine the studies which preceded and generated the current urban climate - none more central to the issue than the Crime Prevention Through Environmental Design (CPTED). As a response to what he saw as a 'destruction of social framework through failed urban renewal strategies,' criminologist C. Ray Jeffery, coined CPTED in 1971, calling for "the development of an interdisciplinary behavioral science of crime and prevention." In this section, I concisely address Elizabeth Woods' efforts while she was the director of the Chicago Housing Authority and oversaw public housing projects. I document her view of public surveillance techniques and the way in which she influenced early iterations of CPTED. I examine Oscar Newman's defensible space theory and address the four main components he identified as being crucial to creating a defensive space. I review the early iterations of CPTED as constructed by Jeffery and address the six broad characteristics identified by the first generation CPTED; territoriality, surveillance, access control, image/maintenance, activity programming, and target hardening. I finally discuss target hardening and the 'dark side' of CPTED, which has resulted in the loss of truly democratic public spaces and caused hostile architecture to become a mainstay in urban environments.

\footnotetext{
${ }^{1}$ Jeffery, C. "Criminology as an Interdisciplinary Behavioral Science.” March 7, 200616 (n.d.).
} 


\section{Elizabeth Wood and the Chicago Housing Authority}

Amidst a desperate housing shortage in post-Great Depression Chicago, Wood was appointed the first Executive Director of the Chicago Housing Authority and oversaw the development of three high rise housing projects catering to middle and lower-class Americans. In a time of social unrest, Wood had the difficult task of improving the living situations of residents while simultaneously attempting to curb racial tensions within the complexes she oversaw.

Wood strove to establish a surrounding environment that was rich and fulfilling for tenants while improving and expanding the aesthetic qualities of the residences they lived in. ${ }^{2}$ During advancements and additions to the shared facilities and outdoor spaces, Wood identified security as a crucial issue, developing a series of guidelines, predominantly advocating for designs that created inherent visibility within the housing complexes she oversaw. Wood believed that by incorporating open spaces to support assorted gatherings, the natural surveillability of the complex would rise, creating an environment where residences are overseen and observable by neighbors or passersby. ${ }^{3}$ Surveillability today is understood to include ecological factors such as lighting or vegetation surrounding a residence. ${ }^{4}$

Ultimately, Wood's ideas were never widely put into practice within the complexes she oversaw, and consequently, the validity of her ideas were never subjected to rigid empirical testing. ${ }^{5}$ However, much of her later writings reflecting on her work as the head of the Chicago Housing Authority greatly influenced the foundational work behind surveillability concepts within early CPTED iterations.

\footnotetext{
2 ibid

${ }^{3}$ Jennings, Wesley. The Encyclopedia of Crime and Punishment. Chichester, West Sussex, UK : John Wiley \& Sons, Boston, Massachusetts, n.d.

${ }^{4}$ Hall, Cason Leafe. "No Crime by Design? Crime Deterrence and Urban Design Reform in the USA after World War II," n.d., 97.

5 ibid
} 


\section{Oscar Newman: Defensible Space Theory}

Newman pioneered the term defensible space in his 1972 book Defensible Space, People and Design in the Violent City. Its implementation proved somewhat trivial as Newman's ideas were lost in the mix between popular ideology and practical implementation because of the ambiguity of his communication and lack of clear imagery. ${ }^{6}$ Despite his mixed success, Defensive Space synthesized and formed many of the basic principles used in CPTED and United States crime prevention.

Newman's writings are focused on urban housing projects, in particular, Pruitt-Igoe in St. Louis (fig. 1,2). Built in 1954, this housing complex was infamous for its crime, poverty and racial segregation, symbolizing the failure of mid-century urban renewal projects. Newman noted that public spaces were crime ridden, vandalized and dirty while most private spaces were decidedly better maintained. ${ }^{7}$ Based on these observations, he argued that it was possible to design public environments in a way which granted greater control to residents, while constructing physical layouts to act as natural deterrents against criminal offenses.

Based on these observations, the term "defensible space" was established; defined as a residential environment whose physical characteristics — building layout and site planfunctioned to allow inhabitants themselves to become key agents in ensuring their security. ${ }^{8} \mathrm{He}$ believed that through adopting a model focused on fostering a sense of responsibility over a communal area in which residents can "extend the realm of their homes and the zone of felt responsibility," criminal acts would decrease, resulting in safer living conditions.

\footnotetext{
${ }^{6}$ Newman, Oscar. "Creating Defensible Space," n.d., 126.

${ }^{7}$ Donnelly, Patrick G. "Newman, Oscar: Defensible Space Theory.” In Encyclopedia of Criminological Theory, by Francis Cullen and Pamela Wilcox. 2455 Teller Road, Thousand Oaks California 91320 United States: SAGE Publications, Inc., 2010. https://doi.org/10.4135/9781412959193.n185.

${ }^{8}$ Newman, Oscar. "Creating Defensible Space," n.d., 126.
} 
Newman furthermore identified four main concepts: territoriality, surveillance, image and milieu, which became the backbone of the defensible space theory and influenced initial iterations of CPTED. He defines territoriality as 'the capacity of the physical environment to create perceived zones of territorial influences, further explaining that the sub-division of space into zones of influence should result in a clear delineation between public, private and semiprivate spaces. ${ }^{9}$ This in turn creates a hierarchy of space ranging from totally private to fully public (fig. 3), suggesting that the capability of a resident to defend certain aspects of their homes is directly connected to the level of innate privacy within a certain space.

Within the hierarchy of a traditional suburban home, a walled rear garden or yard would be described as "fully private" with the owner having complete control over it. A walled front garden could be described as "semi-private" space, because although it is still owned by the resident, there is an implied invitation into the space. The owner still dictates behavior rules but still conveys some level of influence. Conversely, if there was no wall separating the front yard from an adjoining sidewalk or street, the open garden is no longer as easy to defend. There is no physical boundary defining the space, and the behavioral dynamic further changes with the owner ceding control of the space. An adjacent sidewalk could be defined as "semi-public"; the resident doesn't own it but can still regularly observe and potentially influence activities that happen. However, a neighborhood road would be categorized as fully public and subsequently, the owner is without any physical or symbolic influence.

Much like Wood, Newman believed that natural surveillance was essential and should be designed into cities, allowing any citizen to act as a monitor at all times. This creates a state of conscious visibility, while fostering an internalized and self-imposed social control system: as

${ }^{9}$ ibid 
identified in models such as Foucault 's panopticon. ${ }^{10}$ Newman believed that by adding adequate lighting, reducing or eliminating physical barriers to visibility, and promoting clarity in key areas (entrances, lobbies, waiting areas, parking areas), social-behavioral rules were further enforced leading to greater levels of safety and accountability. ${ }^{11}$

Newman also strongly encouraged the use of electronic surveillance particularly in semipublic spaces or "blindspots" (difficult to surveil spaces). This was one of the most damaging of the defensible space proposals as it pushed for a dramatic increase in uninterrupted monitoring, severely undermining personal privacy for residents in semi-public spaces. ${ }^{12}$ However, natural and electronic surveillance were both key aspects in the original CPTED model, and have become pervasive in nearly all facets of modern life.

Newman's discussion around image and milieu focus on dense, high rise projects, arguing that the aesthetic of the development greatly contributes to the stigmatization of the project and its residents. He suggests that the location of public housing projects within the broader community milieu distinctly impacts the safety and perceived security of the project; this in turn impacting residents and the community at large. Specifically, he recommends that these projects should not be built in areas that have high crime rates; rather, they should be located adjacent to safe activity areas such as busy public streets or government institutions. Newman is careful to clarify that image and milieu do not alone reduce unwanted activity, and must work in conjunction with surveillance and territorial techniques to effectively generate a thoroughly defensible space. ${ }^{13}$

\footnotetext{
${ }^{10}$ Caluya, Gilbert. "The Post-Panoptic Society? Reassessing Foucault in Surveillance Studies." Social Identities 16, no. 5 (September 2010): 621-33. https://doi.org/10.1080/13504630.2010.509565.

${ }^{11}$ Newman, Oscar. "Creating Defensible Space," n.d., 126.

${ }^{12}$ Hall, Cason Leafe. "No Crime by Design? Crime Deterrence and Urban Design Reform in the USA after World War II," n.d., 97.

13 ibid
} 
Despite heavy criticism from other criminologists, within two years of Newman's publication, the Law Enforcement Assistance Administration (LEAA) funded a multi-million dollar project to study crime in various cities across the United States. ${ }^{14}$ Portland, Oregon; Broward County, Florida; and Hartford Connecticut were among the first to implement his design strategies, each making changes to outdoor lighting, traffic patterns, road sizes, and landscaping. Evidence suggests that each of the projects had minimal impacts on actual occurrence of street crime. ${ }^{15}$

\section{Crime Prevention Through Environmental Design and Exclusionary Design}

Crime Prevention Through Environmental Design (CPTED) is aimed at "preemptively identifying conditions of physical and social environments that support criminal opportunities and altering those conditions so that no crimes occur. ${ }^{{ }^{16}}$ Criminologist C. Ray Jeffery was at the forefront of CPTED creation, through his 1971 book Crime Prevention through Environmental Design. Jeffery's goal was to design a built environment which, in theory, could control "unwanted" and "hazardous" social or behavioral patterns within varying degrees of privacy.

The original CPTED approach was heavily influenced by the behavioral learning theory proposed by psychologist B. F. Skinner. He believed that all behaviors were acquired through conditioning, which occurs through interaction with the environment, and in turn shapes our actions. ${ }^{17}$ Skinner was known for his criticisms of earlier introspective, or mentalistic, theories of behavior, that are not empirically testable. To avoid this problem, Skinner ignored the human

\footnotetext{
${ }^{14}$ Jusiewicz, David Joseph. "Crime Prevention Through Environmental Design: Crime free Multi-Housing in Arlington, Texas," n.d., 71.

${ }^{15}$ Paulsen, D.J., Robinson, M.B. (2004). Spatial aspects of crime: theory and practice. Boston, MA: Allyn \& Bacon.

${ }^{16}$ Jusiewicz, David Joseph. "Crime Prevention Through Environmental Design: Crime free Multi-Housing in Arlington, Texas," n.d., 71.

${ }^{17}$ Krapfl JE. Behaviorism and Society. Behav Anal. 2016;39(1):123-9. doi:10.1007/s40614-016-0063-8
} 
brain entirely, opting to solely observe the actions he saw, rather than guess what he believed to be in the organism's brain. Jeffery took a very similar approach with his design proposals, suggesting that the environmental conditions which altered behaviors, worked in a one-way relationship without first affecting the offender. ${ }^{18}$

The original findings of CPTED were revised in a 1977 publication, but it wasn't until 1990, in Jeffery's book Criminology: An Interdisciplinary Approach, that his model evolved into a fleshed-out program. In his own words, the basic assumption of the CPTED is:

"the response [i.e. behavioral adaptation] of the individual organism to the physical environment is a product of the brain; the brain in turn is a product of genetics and the environment. The environment never influences behavior directly, but only through the brain. Any model of crime prevention must include both the brain and the physical environment. "19

Thus, the six main CPTED considerations were formed: territoriality, natural surveillance, access control, activity support, image, management and target hardening (fig. 4).

\section{Territoriality}

Territoriality is a design concept directed at reinforcing notions of proprietary concern and a "sense of ownership" in legitimate users of the space, thereby reducing opportunities for offending by discouraging illegitimate users. ${ }^{20}$ In CPTED, different forms of barriers ranging from physical (fences, landscaping) to symbolic implementations (signage) are encouraged. CPTED emphasizes crime prevention techniques that exploit opportunities in the environment

\footnotetext{
${ }^{18}$ Paulsen, Derek. Spatial Aspects of Crime. Pearson/Allyn and Bacon, 2004.
}

${ }^{19}$ Jeffery, C R, and D L Zahm. "Crime Prevention Through Environmental Design, Opportunity Theory, and Rational Choice Models (From Routine Activity and Rational Choice." Advances in Criminological Theory 5 (1993): 323-50.

${ }^{20}$ Cozens, Paul, Greg Saville, and David Hillier. "Crime Prevention Through Environmental Design (CPTED): A Review and Modern Bibliography.” Property Management 23 (December 1, 2005): 328-56. 
both to naturally and routinely facilitate access control and surveillance, and to reinforce positive behavior in the use of the environment ${ }^{21}$ These not only clearly delineate private and public space as specified by Newman, but promote opportunities for natural surveillance to occur.

\section{Natural Surveillance}

CPTED suggests that physical design within the built environment has the ability to provide natural surveillance opportunities for residents and the greater community alike. As stated by both Wood and Newman, if offenders perceive that they can be observed, the likelihood of them committing a criminal act decreases significantly. Natural Surveillance is further assisted by avoiding low levels of lighting, thick trees or shrubbery, or any similar forms which provide opportunities for concealment. It is important to note that even if the physical environment lends itself to natural surveillance, it does not mean that surveillance is always taking place. This is why Jeffery later pushed for crime prevention models that addressed the brain and physical environments, rather than just adjustments to the built environment like he initially proposed.

\section{Access Control}

Access control focuses on reducing opportunities for crime by denying access to potential targets and creating a heightened perception of risk in offenders. ${ }^{22}$ Strategies are separated into informal, formal, and mechanical methods, each meant to target a different access point. Informal methods are focused around spatial organization with the intention of controlling free movement to reduce the number of spatial variables. Security personnel form the majority of

\footnotetext{
${ }^{21}$ Crowe, Timothy. Crime Prevention Through Environmental Design: Applications of Architectural Design and Space Management Concepts. Butterworth-Heinemann, 1991.

22 Cozens, Paul, Greg Saville, and David Hillier. "Crime Prevention Through Environmental Design (CPTED): A Review and Modern Bibliography.” Property Management 23 (December 1, 2005): 328-56.
} 
formal methods, while mechanical methods refer to the use of locks, bolts and other security measures.

\section{Activity Support}

Activity support involves the use of design and signage to encourage intended patterns of usage of public space. Activity generation seeks to place inherently "unsafe" activities such as those involving money transfers, in 'safe' locations (those with high levels of public activity and surveillance opportunities.) Similarly, "safe activities serve as magnets for ordinary citizens who may then act to discourage the presence of criminals." ${ }^{, 23}$ At its core, activity support guidelines seek to promote street level activity within surveillable spaces in order to foster a community that is engaged with their territory. Active and engaged communities demonstrate acceptable behaviors and foster an environment where criminal acts are easily recognizable and discouraged.

\section{Image / Management}

Image and management is concerned with public perception and calls for routinely maintaining the built environment to ensure that positive signals are transmitted to the users and viewers of the space. It has long been understood that criminal acts and the fear of criminal offences correlates to the image and upkeep of the surrounding physical environment. CPTED proposes that proper management is essential for other aspects of the program to function. Well maintained living complexes foster a greater sense of overall community and provide residents with a greater sense of safety. A strong community leads to higher activity levels on the streets, territorial enforcement, and natural surveillance; all of which foster a defensible space.

${ }^{23}$ Crowe, Timothy. Crime Prevention Through Environmental Design: Applications of Architectural Design and Space Management Concepts. Butterworth-Heinemann, 1991. 


\section{Target Hardening}

Target hardening can be implemented in many ways and is simply about complicating criminal activity. It is a well-established and commonly applied strategy to reduce burglary, theft of or from motor vehicles, and graffiti. ${ }^{24}$ Target Hardening attempts to go beyond the conventional crime prevention tactics, through implementing additional fences, gates, locks, electronic alarms and security patrols. While similar to other CPTED guidelines, target hardening specifically addresses the overall strengthening of a structure rather than open public space. This is controversial as the excessive use of target hardening tactics can create a 'fortress mentality' whereby residents withdraw behind physical barriers, and the self-policing capacity of the built environment is damaged, ultimately working against other guidelines set by CPTED. ${ }^{25}$ The over-fortification of buildings due to target hardening can be seen in various environmental settings including gated communities, public spaces, malls, the night economy, and nightclubs. ${ }^{26}$ This over fortification is a major factor in the decrease of democratic public spaces as it encourages exclusionary design which inherently targets underrepresented populations.

\section{Exclusionary Design}

Ideally, CPTED is used in an egalitarian manner to support the law. However, CPTED has intrinsic exclusionary properties as many principles are intended to remove offenders/criminals from certain spaces. The exclusionary properties of CPTED can be (and have been) used to provide privilege to some groups at the expense of others. ${ }^{27}$ This thinly veiled

${ }^{24}$ Cornish, Derek B, and Ronald V Clarke. "Opportunities, Precipitators and Criminal Decisions: A Reply to Wortley's Critique of Situational Crime Prevention," n.d., 56.

${ }^{25}$ Cozens, Paul, Greg Saville, and David Hillier. "Crime Prevention Through Environmental Design (CPTED): A Review and Modern Bibliography." Property Management 23 (December 1, 2005): 328-56.

${ }^{26}$ Cozens, Paul, and Terence Love. "The Dark Side of Crime Prevention Through Environmental Design (CPTED).'In Oxford Research Encyclopedia of Criminology and Criminal Justice, by Paul Cozens and Terence Love. Oxford University Press, 2017. https://doi.org/10.1093/acrefore/9780190264079.013.2.

${ }^{27}$ ibid 
aspect of CPTED exposes the destructive nature this program can have on social fabric within built environments. CPTED places a large focus on identifying "legitimate" and "illegitimate" users of a space and designing public space in a manner which accounts for these two perceived categories. This process ignores preconceptions regarding race, ethnicity, socioeconomic status, and gender, and fails to acknowledge that CPTED is inherently a value driven program and cannot be implemented without bias. Critically, the subjectivity and lack of attention to the political and ethical issues involved in making these kinds of decisions are not commonly addressed in CPTED literature. ${ }^{28}$ Indeed, sociologist Patrick Parnaby has argued that "the fact that members of a community may run the risk of excluding citizens on the basis of discriminatory criteria is not even acknowledged... [that the] sorting of people ... may or may not be accurate, let alone ethical." ${ }^{29}$ Consequently, the manipulation of CPTED guidelines create a design approach which attempts to construct a homogeneous society, free from otherness, through the utilization of hostile architecture and exclusionary design techniques.

\section{$\underline{\text { Hostile Architecture: Typologies, Intentions and Implications }}$}

\section{Introduction}

Hostile architecture is a term used to broadly characterize built forms which, when installed in public spaces, render them unusable for groups of citizens, or activities, deemed "undesirable." Much of the inherent power which CPTED-based hostile architecture holds over urban spaces is through the constriction of truly "free" public space, particularly for homeless individuals, or those who are marginalized in society. Homelessness and transient lifestyles have

\footnotetext{
28 ibid

${ }^{29}$ Parnaby, Patrick. "Crime Prevention through Environmental Design: Discourses of Risk, Social Control, and a Neo-Liberal Context” 48 (January 2006).
} 
long been signifiers of "otherness" and have extensive histories of exclusion, stigmatization, and punitive treatment. A 2004 study found that a modern city actively aims to erase images of poverty, social decay, and public disorder to attract commerce, investment, and fulfill utopian desires — all notably absent of "undesirable" citizens; ${ }^{30}$ leading to what criminologist Jock Young deems an "exclusive society." 31

In this section, I identify and describe the most common forms of hostile architecture, and how they restrict democratic urban spaces. I have chosen to separate hostile implementations into three sections based on classifications proposed by photographer John Michael Kilbane, who documented urban hostility in New York City. I first examine devices which alter public seating, in particular the Camden Bench; a perfect anti-object. I analyze hostile architecture that affects surfaces in order to carefully regulate and prevent unwanted activities such as sleeping, loitering or panhandling. Through examining the redevelopment of downtown Los Angeles, I discuss the implications of a sweeping hostile design language, and how this approach removes marginalized citizens from urban spaces. I also acknowledge that while electronic monitoring techniques, specifically: surveillance, noise generation, and ultraviolet lighting, are exclusionary techniques frequently used, I will be focusing on architectural elements in order to create a clear and concise analysis of constructed hostile devices.

\section{Seating}

Sittable public spaces are essential to the health of a thriving urban core. Available seating is one of the most important features of the urban space where comfort is concerned: a

\footnotetext{
${ }^{30}$ Gerrard Jessica and David Farrugia, The 'Lamentable Sight' of Homelessness and the Society of the Spectacle (Urban Studies Journal Limited 201452 (12): 2219-33.)

${ }^{31}$ De Fine Licht, Karl Persson. "Hostile Urban Architecture: A Critical Discussion of the Seemingly Offensive Art of Keeping People Away." Etikk i Praksis - Nordic Journal of Applied Ethics 11, no. 2 (November 14, 2017): 27. https://doi.org/10.5324/eip.v11i2.2052.
} 
bench is a place to be private in public, a small space in the melee of the metropolis where it is acceptable to do nothing, to consume nothing, to just be. ${ }^{32}$ Despite a broad consensus around the importance of such urban enclaves, hostile benches, as defined below, have largely taken over as the dominant typology represented in public spaces, restricting how individuals act within urban cores.

Designed by UK company Factory Furniture, the Camden bench (fig. 5) first appeared in London, specifically commissioned to deter anti-social behavior. ${ }^{33}$ While it may look simple in its design, it is carefully constructed to prevent, if not outright eliminate, unwanted public activities such as sleeping, or panhandling. The bench features a cold, hard, unforgiving concrete exterior with angled surfaces, making sleeping or sitting for an extended period of time near impossible. The surface is further coated with a waterproof, anti-paint coating to prevent graffiti, scraping, or other types of vandalism. The bench is free of crevices or impressions, preventing drug exchanges, or places for occupants to leave personal items or litter. The irregular shape even makes the surface unusable for skateboarders who prefer an even edge to skate along.

The Camden bench is an extreme example of placing municipal demands over urban aesthetics, as well as the wellbeing of citizens across the socioeconomic spectrum. The concrete may provide a place of respite for a businessperson on a brief break, but it offers no place of shelter for disenfranchised individuals who, out of necessity, turn to public spaces for shelter. It is the perfect anti-object, as Design Journalist Frank Swain comments:

"It is a strange artifact, defined far more by what it is not than what it is. The Camden Bench is a concerted effort to create a non-object. [It] is a strange kind of architectural

\footnotetext{
32 Struthers, Kristen. "Why the City Bench Is the Unsung Hero of Good Public Spaces." Nadi (blog), April 8, 2019. https://insights.nadi.design/why-the-city-bench-is-the-unsung-hero-of-good-design.

${ }^{33}$ Gamman, Lorraine and Willcocks, Marcus (2011) The Anti-bag Theft and ASB-resistant "Camden Bench". Other. Design Against Crime.
} 
null point. A piece of the city that by design will not interact with it in any way. It is a bench by the slimmest of margins - hardly comfortable, affording none of the qualities that would make it more than simply a place to sit. This is the bench's sole concession to

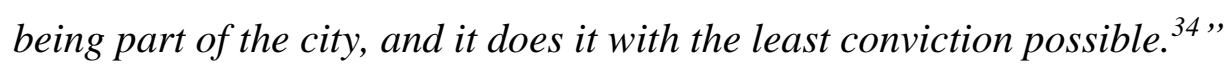

Swain's statements point toward the broader social implications behind urban additions such as these, and the dangerous precedent that is set. The Camden Bench establishes a socioeconomic bar within public spaces, and consequently limits who can fully interact with differing parts of a city. This not only reduces the amount of truly "free and democratic space" within an urban environment, but continues to criminalize severely disenfranchised populations, further limiting their ability to meet basic human needs. This ill-founded approach is perpetuated further through comments made by the Factory Furniture design team, arguing in defense of their work:

"Homelessness should never be tolerated in any society and if we start designing to accommodate the homeless then we have totally failed as a society. Close proximity to homelessness unfortunately makes us uncomfortable so perhaps it is good that we feel that and recognize homelessness as a problem rather than design to accommodate it. ${ }^{35}$, Architecture like this reacts to what is portrayed as an aesthetic concern within the urban landscape, carefully avoiding the actual issue at hand. Rather than addressing the root of disenfranchisement in the United States, designs such as these target and condemn the victims of a modern capitalist city.

\footnotetext{
${ }^{34}$ Swain, Frank. "Designing the Perfect Anti-Object." Medium (blog), December 5, 2013. ttps://medium.com/futures-exchange/designing-the-perfect-anti-object-49a184a6667a.

${ }^{35}$ Design, Unpleasant. Interview with Factory Furniture Design Team: On Benefits of Unpleasant Design, n.d.http://unpleasant.pravi.me/interview-with-factory-furniture-design-team/.
} 
Aside from the egregious design of the Camden bench, there are other common ways public seating has been modified to prevent unwanted activities. Standard benches are often designed with extra arm rests (fig. 6), at a slight slant or with large gaps to hamper any attempts to lie down. Many public spaces now feature "unsittable benches" (fig. 7) offering a narrow and steeply pitched platform, or a fully rounded tubular design (fig. 8), rendering the act of sitting impossible.

These substitutes for acceptable seating are blatant, and often cause outright confusion among the greater public — socioeconomics aside.

\section{Surfaces}

Surfaces are another major target for hostile architecture, and sleeping rough is generally targeted the most. While surfaces are thematically similar to seating, for the purposes of clearly differentiating between disparate aspects of the urban sphere targeted by hostile architecture, I have chosen to separate the two.

Pig ears (fig. 9,10), a metal protrusion around half an inch tall, are a prevailing technique in hostile architecture. These devices are placed every few feet on nearly all level surfaces, targeting a range of individuals, specifically: the homeless, skateboarders, and teenagers in general, whose activities are seen as disruptive or problematic. Pig ears prevent skateboarders from ollying onto benches and curbs, while deterring homeless individuals from resting. Many other variations based on the effectiveness of pig ears have been developed, as well including lines of metal spikes or bolts that protrude further than pig ears and are visually more combative. Anti-homeless spikes (fig. 11,12) are one of the most aggressive techniques used against the homeless, and heavily compromise anyone's ability to interact with urban spaces. These 
elements, usually ranging from 3 to 6 inches in height, are placed every few inches under covered spaces commonly used by the homeless population.

While incredibly effective at warding off "otherness," anti-homeless spikes in particular have gained an incredibly negative reputation amongst the greater population. These devices were first brought to public attention in June 2014, when social media accounts drew attention to a set of spikes located by a building entrance in South London. ${ }^{36}$ Images were published by major news sites such as the Guardian with Alex Andreou, a journalist who had experienced homelessness after the 2009 stock market crash, commenting on the effect the spikes had:

"The Psychological effect is devastating [for those the architecture is designed against]...Ironically, it doesn't even achieve its basic goal of making us feel safer. There is no way of locking others out that doesn't also lock us in. The narrower the [sic] arrow - slip, the larger outside dangers appear. Making our urban environment hostile breeds hardness and isolation." 37

The public backlash and news coverage, petitions, protests, and pressure from the city government eventually led to the removal of spikes. More importantly, this also represented the first time hostile design transcended the invisible sphere, within the built environment it thrives in, to be critiqued by the public at large who found the devices aesthetically unpleasing and inhumane. Hostile architecture succeeds by meeting municipal demands, adhering to some innate level of inconspicuousness. Anti-homeless spikes function in a similar way to the Camden bench, but only the spikes have faced broad public scrutiny. Because of this, 'aesthetically

\footnotetext{
${ }^{36}$ Petty, James. 2016. “The London Spikes Controversy: Homelessness, Urban Securitisation and the Question of 'Hostile Architecture.'” International Journal for Crime, Justice and Social Democracy 5 (1): 67. https://doi.org/10.5204/ijcjsd.v5i1.286.

37 Andreou, Alex. “Anti-Homeless Spikes: 'Sleeping Rough Opened by Eyes to the City's Barbed Cruelty." The Guardian, February 18, 2015.
} 
pleasing' adaptations upon homeless spikes have progressed, mainly in the form of colorful rocks, or large planters. Neither of which are primarily concerned with urban aesthetics, but rather continued "class based spatial ordering" in public areas.

\section{Class-Based Spatial Ordering}

Hostile architecture is generally understood to encompasses small scale implementations that affect large marginalized groups, but design decisions that isolate groups within a city are often overlooked and categorized as small-scale problems rather than large architectural statements. Orchestrated by a sequence of hostile devices within urban cores, it is important to consider how socioeconomic and race based spatial ordering is accomplished. I will focus on work primarily done by Michael Davis, in his 1990's study of Los Angeles, a notoriously authoritarian methodology was used to establish social isolation between classes, and ensure a seamless continuum of white, middle class existence. ${ }^{38}$ The systems used within the urban core of L.A. establish how these hostile techniques were used to devastate "class free public space," removing images of poverty from the newly developed core of the city.

To armor the city against the poor and drive out unsightly individuals from the developed downtown, L.A. engaged in a relentless campaign to make streets as unlivable as possible. Replacing the imagery of a diverse and thriving urban core, L.A. established a new architectural language and obsession with "designer downtowns, and homogeneous urban renaissance."39 Redevelopers were careful to reduce any accidental cross pollination between white collar workers and homeless citizens through inward development. Davis points toward two main offenders: the Los Angeles Times Headquarters and the Ronald Reagan State Office

${ }^{38}$ Davis Michael, Fortress Los Angeles: The Militarization of Urban Space (Cultural Criminology, Theories of Crime.)

${ }^{39}$ ibid 
Building parking structures. Built by the same redevelopment company, each building was designed with pathways of stunning landscapes, boutique shops and picnic areas, all intended to function as 'confined confidence building circulation methods' to further instill a sense of safety for upper class citizens. ${ }^{40}$ However, outside of this insular utopia, the buildings were enveloped by state of the art security systems, security guards, and even sprinklers which would turn on to prevent unwanted citizens from loitering or sleeping: target hardening measures used to the extreme.

In addition to building specific target hardening, city planners implemented sweeping street level changes. Public facilities such as benches and water fountains and bathrooms were removed and replaced with opulent planters, fountains, and artwork dividing up the last assemblage of downtown public space into small swaths of land, killing any gatherings which might have taken place there previously.

Having made the downtown area unlivable for homeless and marginalized populations, L.A. used aggressive approaches to fully sequester unwanted citizens into certain districts. Davis addresses the Los Angeles Police Department's push to “retake crime plagued MacArthur Park" and surrounding neighborhoods, whose predominant residents were impoverished people of color. While the area was undoubtedly a drug market, it was also home to a multitude of small vendors, who took advantage of the public park to run their family businesses. Through their "restoration effort" the L.A.P.D. took over the park, effectively criminalizing every attempt by the poor (whether illegal or otherwise) to use MacArthur Park for means of survival, abolishing the last safety net separating misery from financial catastrophe. ${ }^{41}$ Programs such as these were repeated in inner-city neighborhoods using "war on drugs" as a continued pretext for all police

40 ibid
41 ibid 
activities. Davis points to a neighborhood just south of MacArthur park who were quarantined in a "narcotics enforcement area" with large concrete barriers restricting entry into the neighborhood, forcing residents further into the inner city. ${ }^{42}$ In the Watts-Willowbrook neighborhood, quarantine measures were taken to the extreme, particularly surrounding the King Shopping Center as described by Jane Buckwater:

"The King center site is surrounded by an eight-foot-high, wrought-iron fence, comparable to security fences around the perimeters of private estates and exclusive residential communities. Video cameras equipped with motion detectors are positioned near entrances and throughout the shopping center. The center, including parking lots, can be better in bright [lights] at the flip of a switch. There are six entrances to the center: three entry points for autos, two service gates and one pedestrian walkway...The service area...is enclosed with a six-foot-high concrete-block wall; both services gates remain close and are under closed circuit video surveillance equipped for two-way voice communications, and operated by remote control from a security 'observatory.' Infrared beams at the bases of light fixtures detect intruders who might circumvent video cameras by climbing over the wall." 43

This extreme use of security and target hardening effectively disbanded all public space surrounding the King Shopping Center and as this technique was repeated throughout inner city neighborhoods, democratic public space disappeared as well. This left impoverished residents, already sequestered into inner city neighborhoods with little democratic space, and homeless individuals with no place to stay, let alone meet their basic human needs.

\footnotetext{
42 ibid

${ }^{43}$ Bukwalter, Jane, “Securing Shopping Centers for Inner Cities,' Urban Land, Apr. 1987, p 24
} 


\section{Conclusion}

The inability to exist in public spaces is still a major problem, and hostile architecture is even more prevalent today in nearly every aspect of public design. Newman, Jeffery, and other pioneers of CPTED theories attempted to establish a program to enhance public safety through the manipulation of the built environment, but instead they established a dangerous precedent for urban space. Democratic public space is now engaged in a constant struggle between cities who wish to dictate the behavior of their inhabitants, and marginalized citizens who turn to public spaces for their very livelihood. The formation of a hostile design language has allowed this power dynamic to shift in favor of the city and has given those in power a reliable control mechanism. This is the real danger of CPTED and hostile architecture: the ability to annihilate space by law. ${ }^{44}$ When implemented in a comprehensive manner, officials can criminalize and target marginalized communities with hostile designs and remove them from the main fabric of society. Because of this, hostile architecture is far more than small implementations across urban spaces. It is an attitude, a meticulous and aggressive methodology, obsessed with the creation of homogeneous utopian societies, free from any imagery of otherness.

When designing cities, officials and designers must consider the impact their decisions have on all sections of the population, and the needs of the marginalized in our society need to be deeply considered; they are the ones who rely the heaviest on free and open public space to survive. Livability in urban spaces should be non-negotiable and not seen as a direct threat to safety within a city. Until a new typology of architecture emerges, one that is based in compassion rather than fear, the erasure of democratic spaces will continue, and cities will further marginalize the underrepresented.

\footnotetext{
${ }^{44}$ Davis Michael, Fortress Los Angeles: The Militarization of Urban Space (Cultural Criminology, Theories of Crime.)
} 


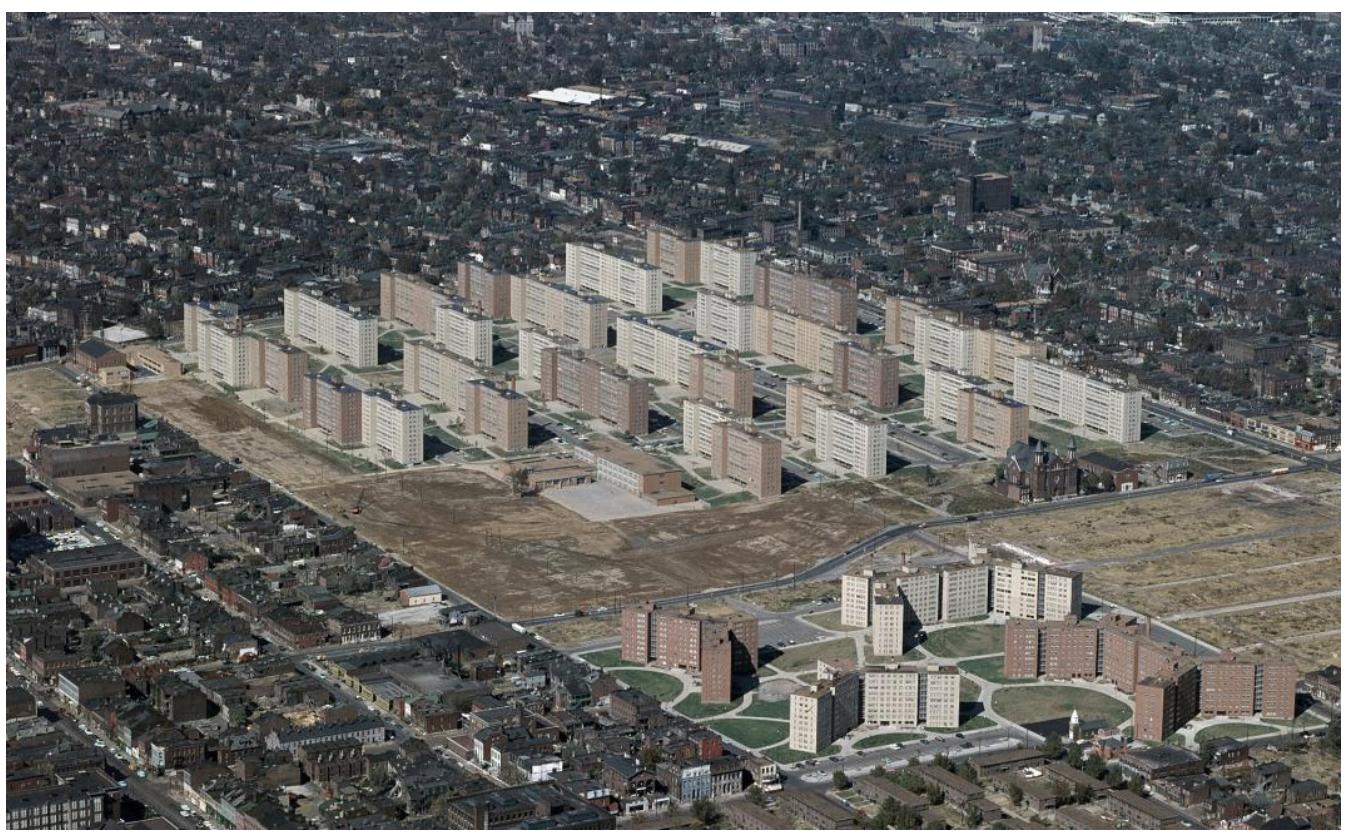

Figure 1: Pruitt-Igoe Housing Projects, Chicago, Illinois

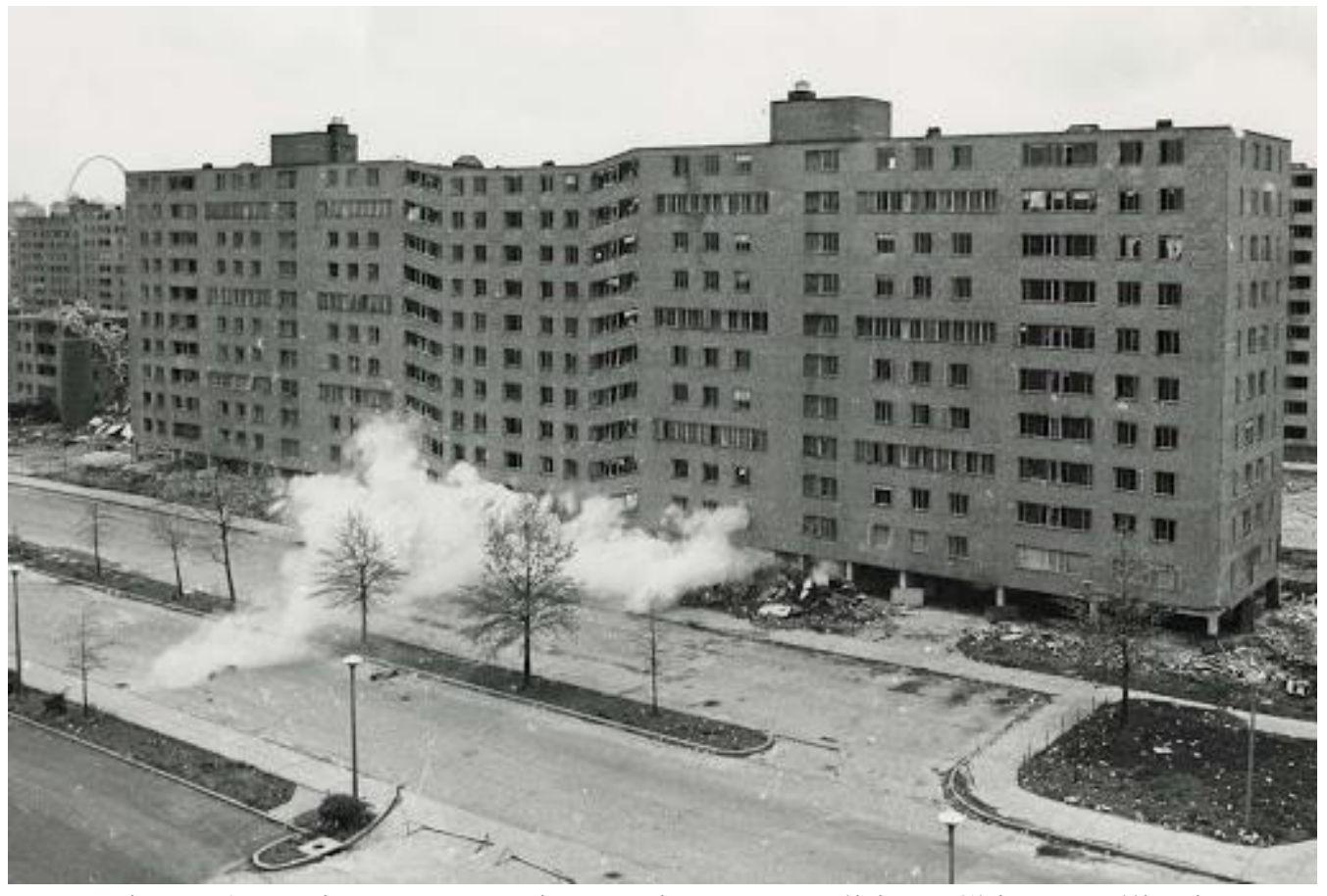

Figure 2: Pruitt-Igoe Housing Projects Demolition, Chicago, Illinois 


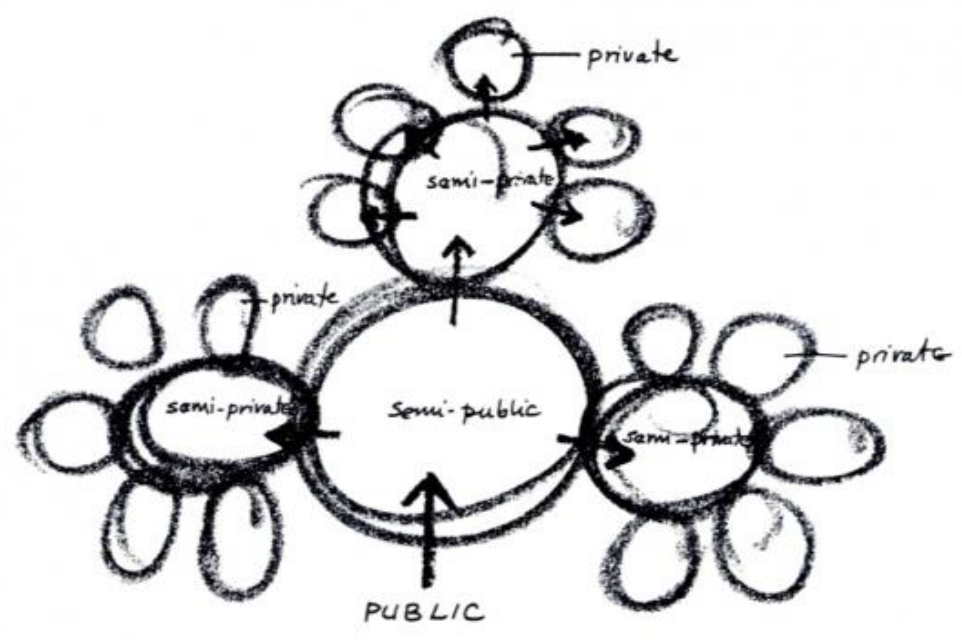

Figure 3: Diagram by Newman of defensible spaces clearly allocated to various residents and small groups of residents.

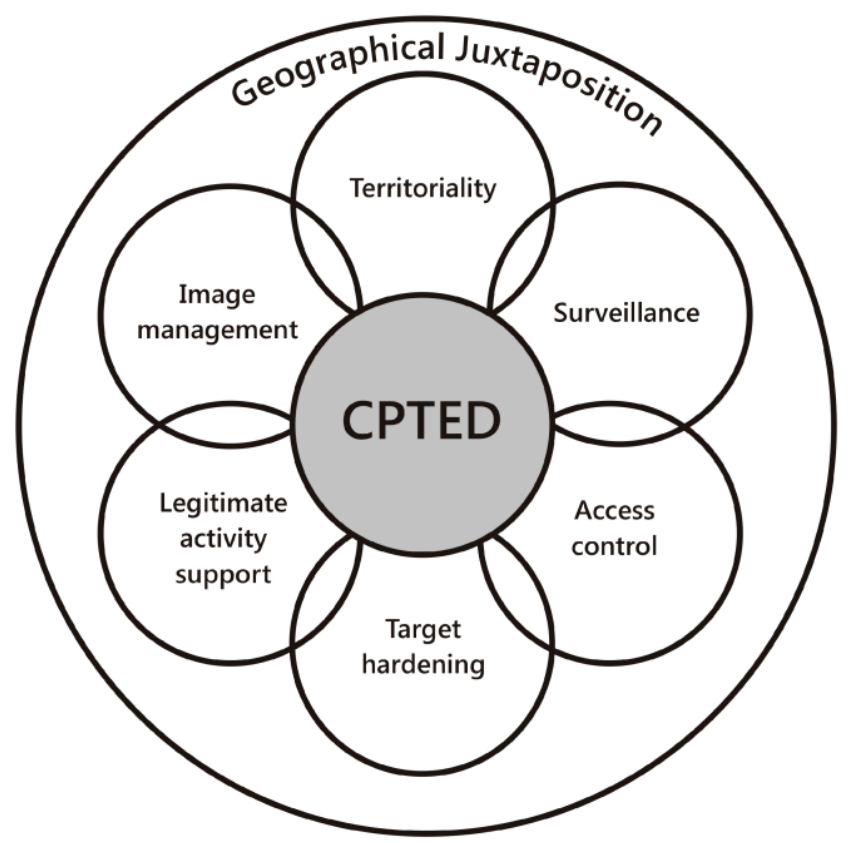

Figure 4: First Generation CPTED Concept Diagram 


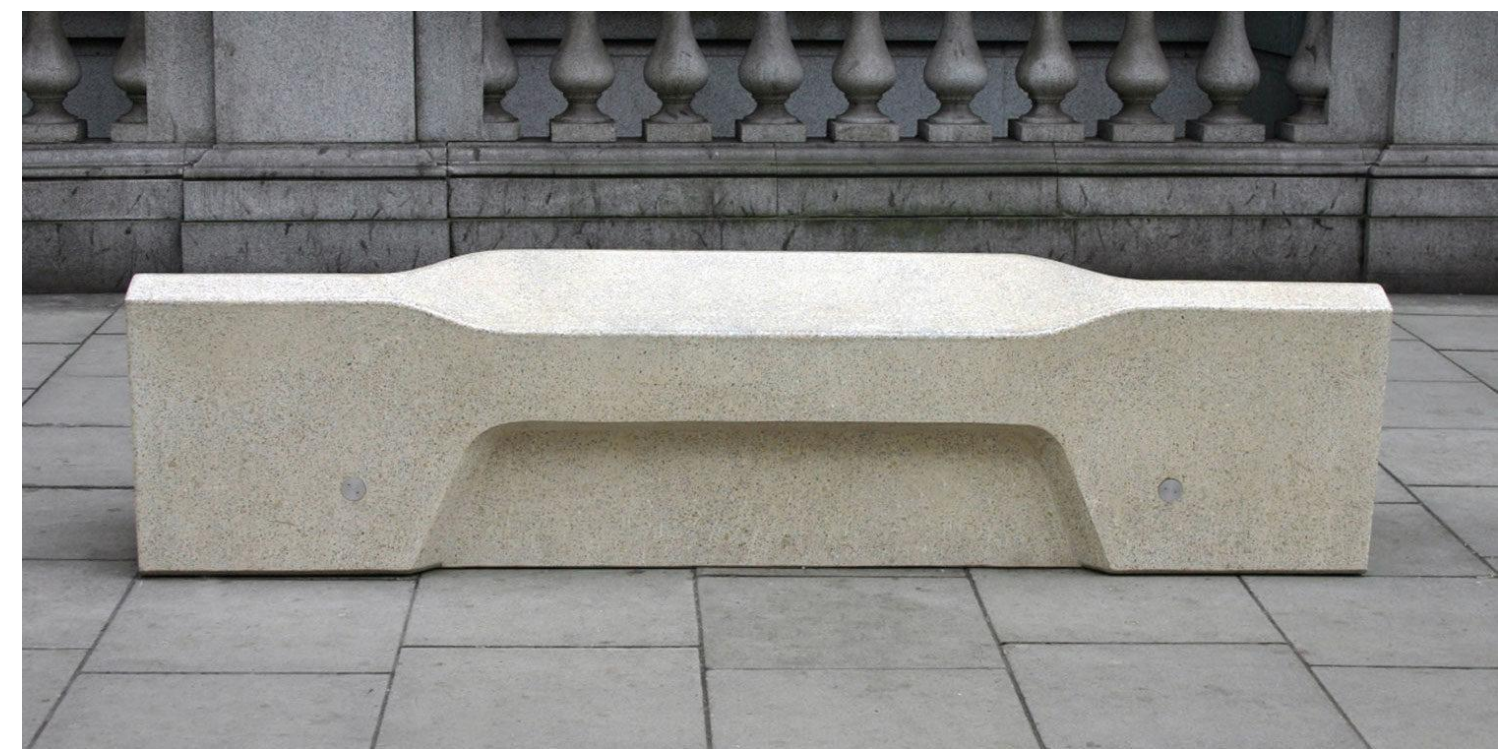

Figure 5: The Camden Bench as Designed by Factory Furniture

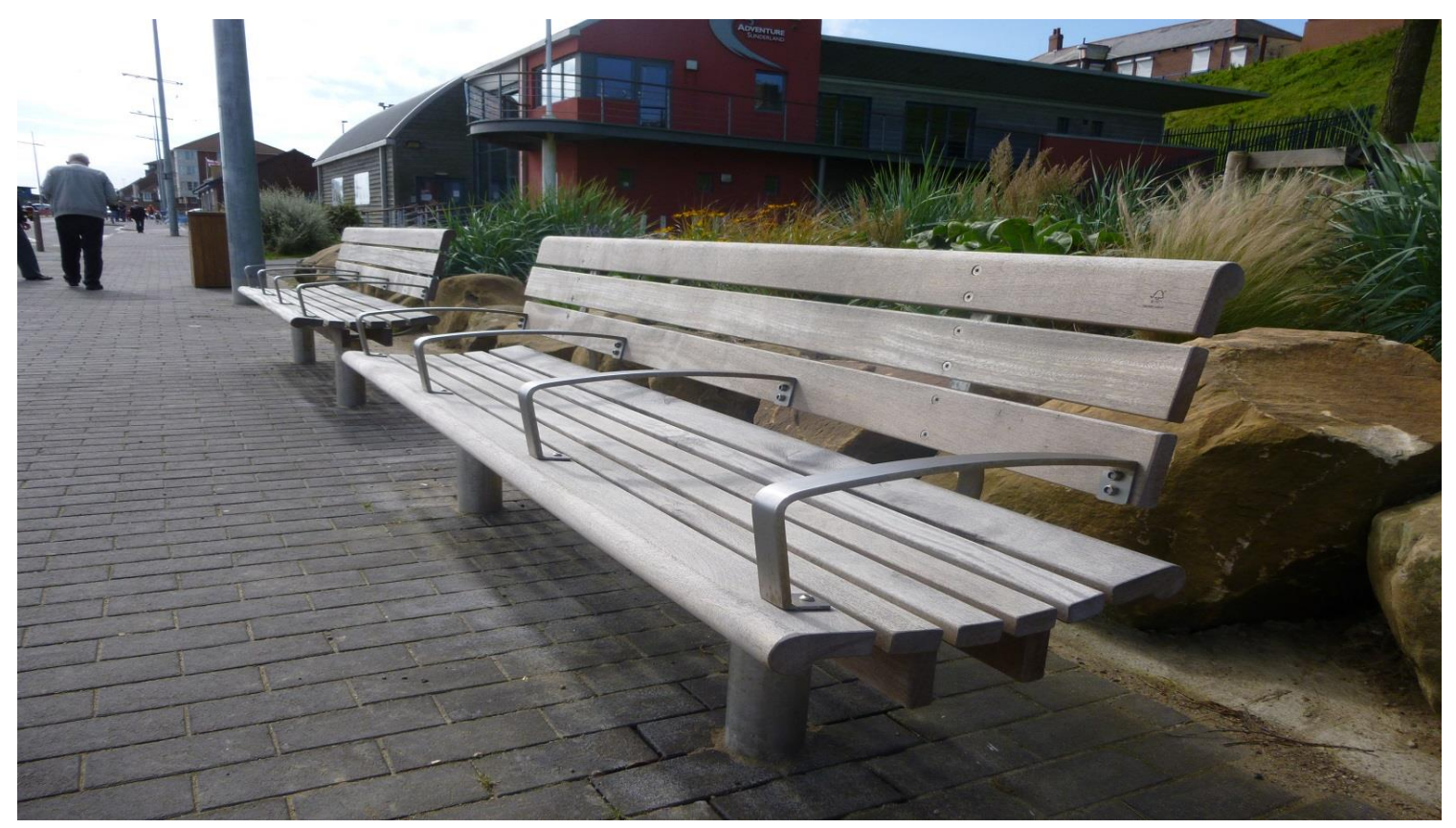

Figure 6: Benches Designed with Additional Arm Rests 
Carr 26

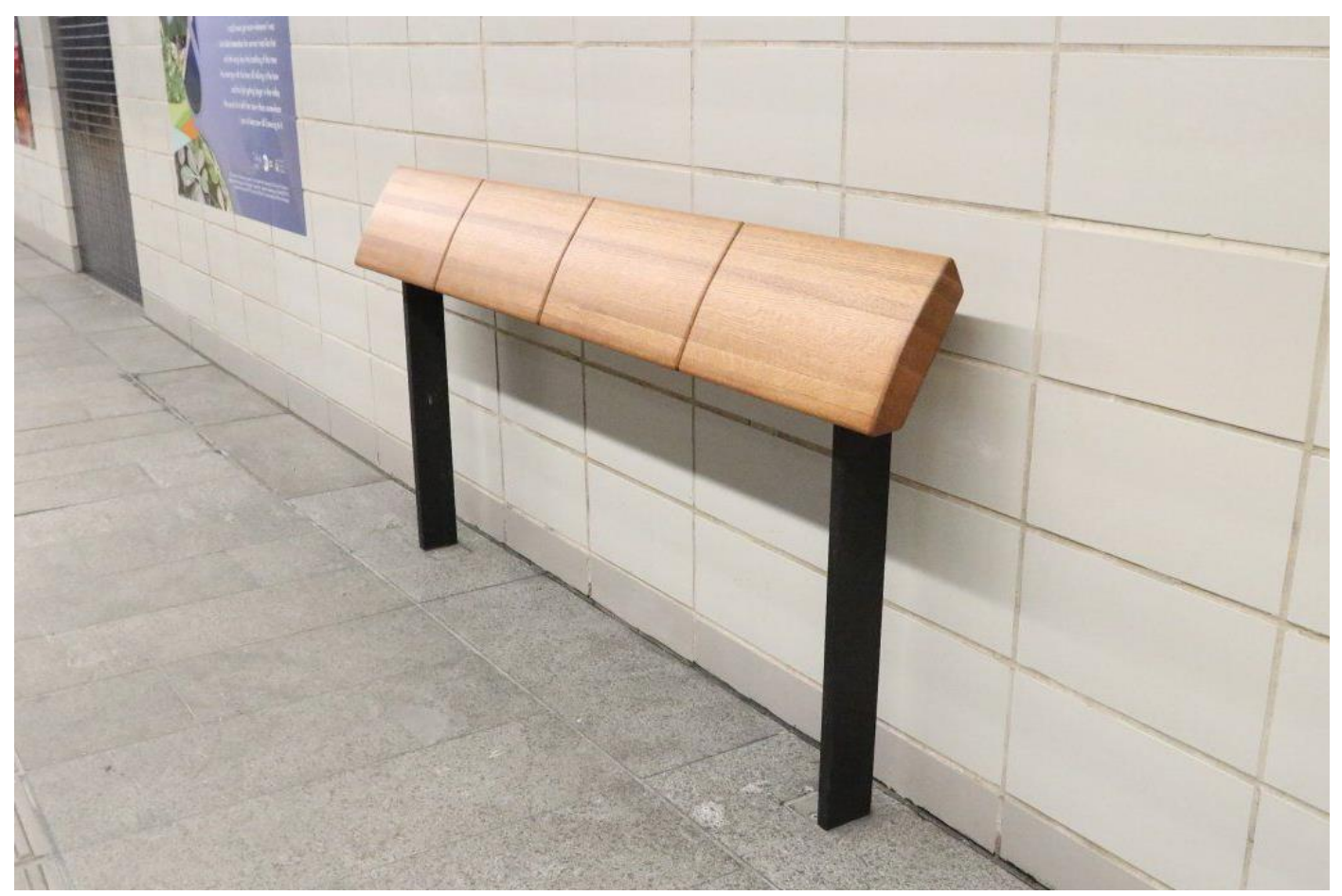

Figure 7: An "Unsittable” Tilted Bench

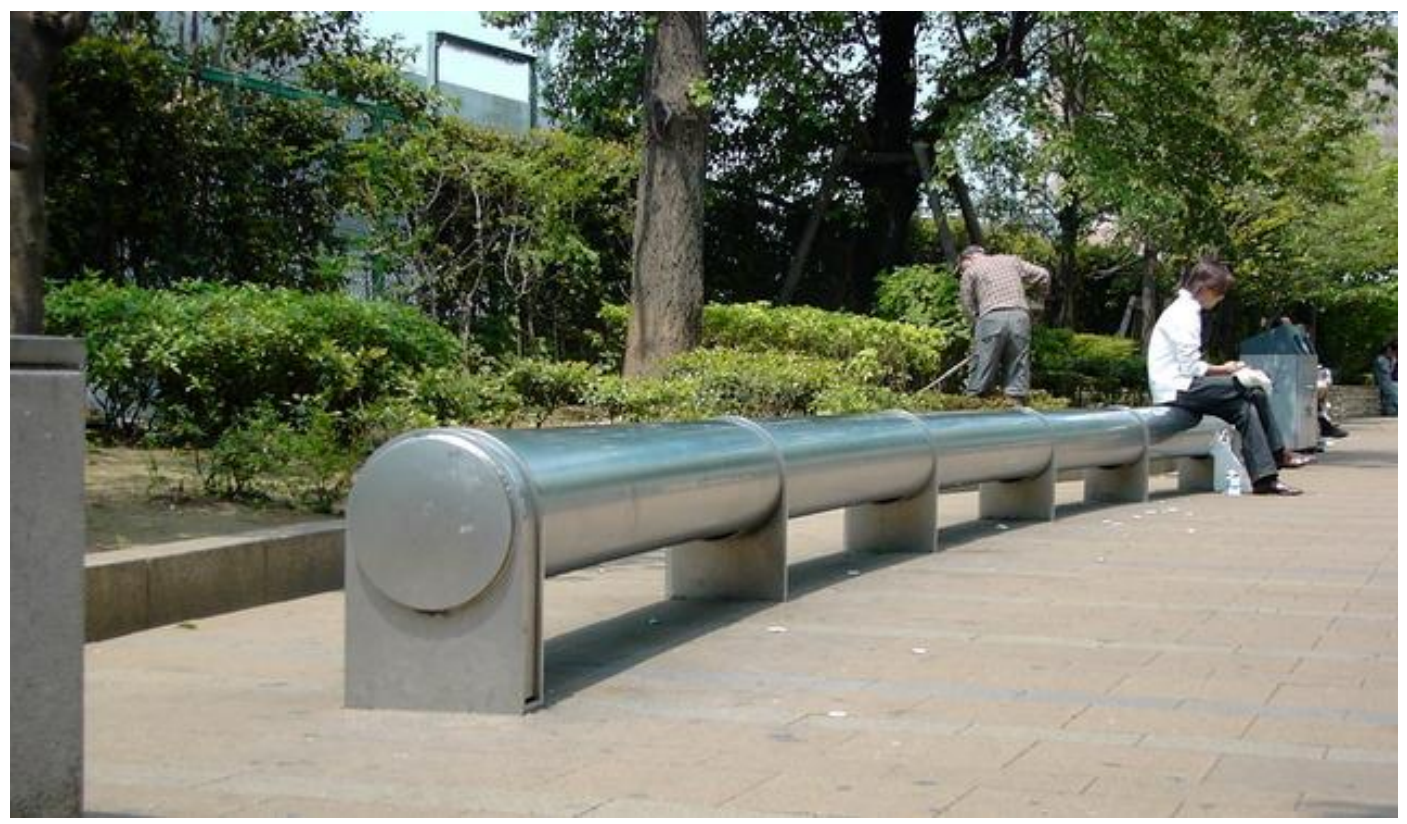

Figure 8: An "Unsittable" Rounded Bench 


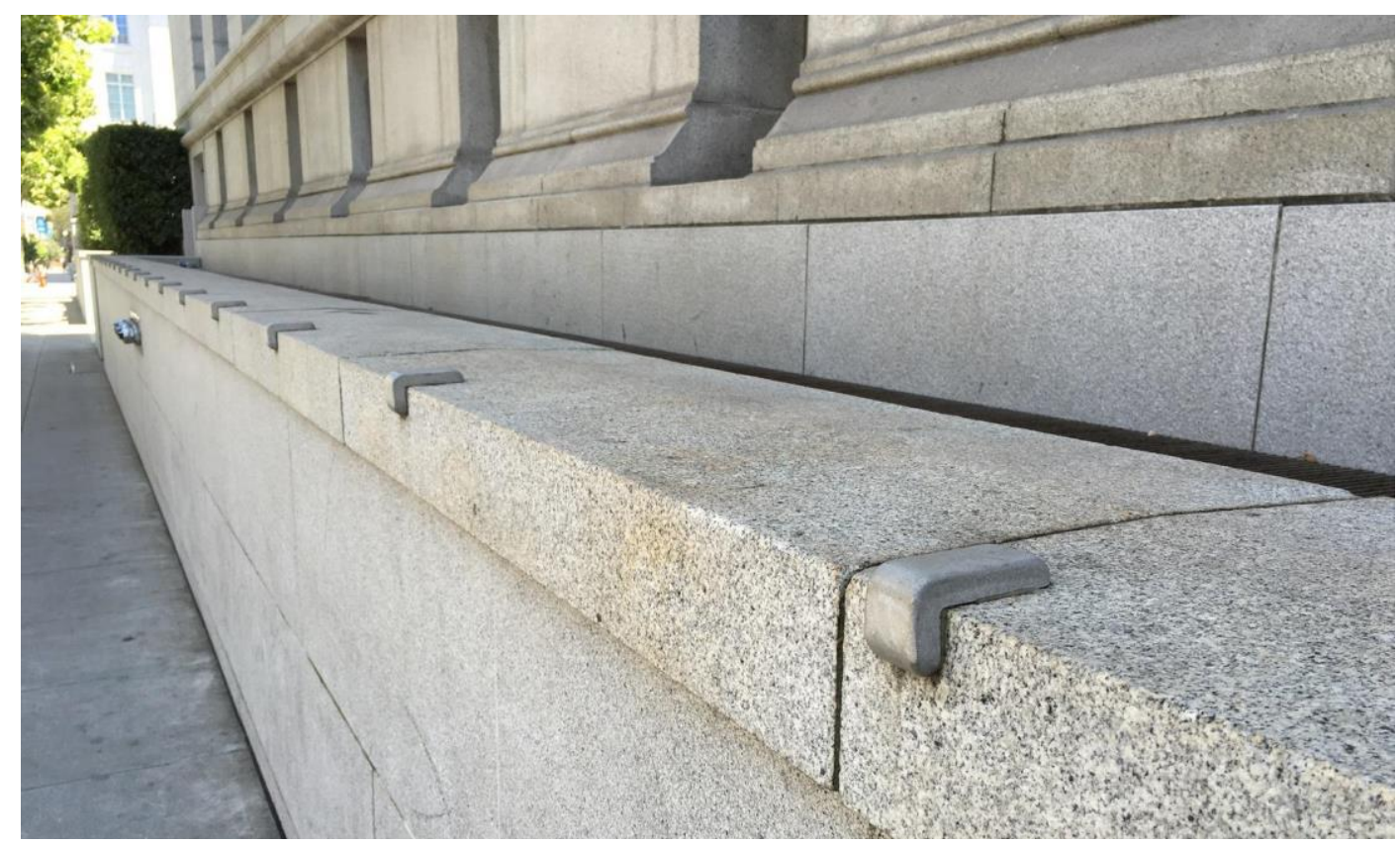

Figure 9: Pig Ears on Public Surfaces

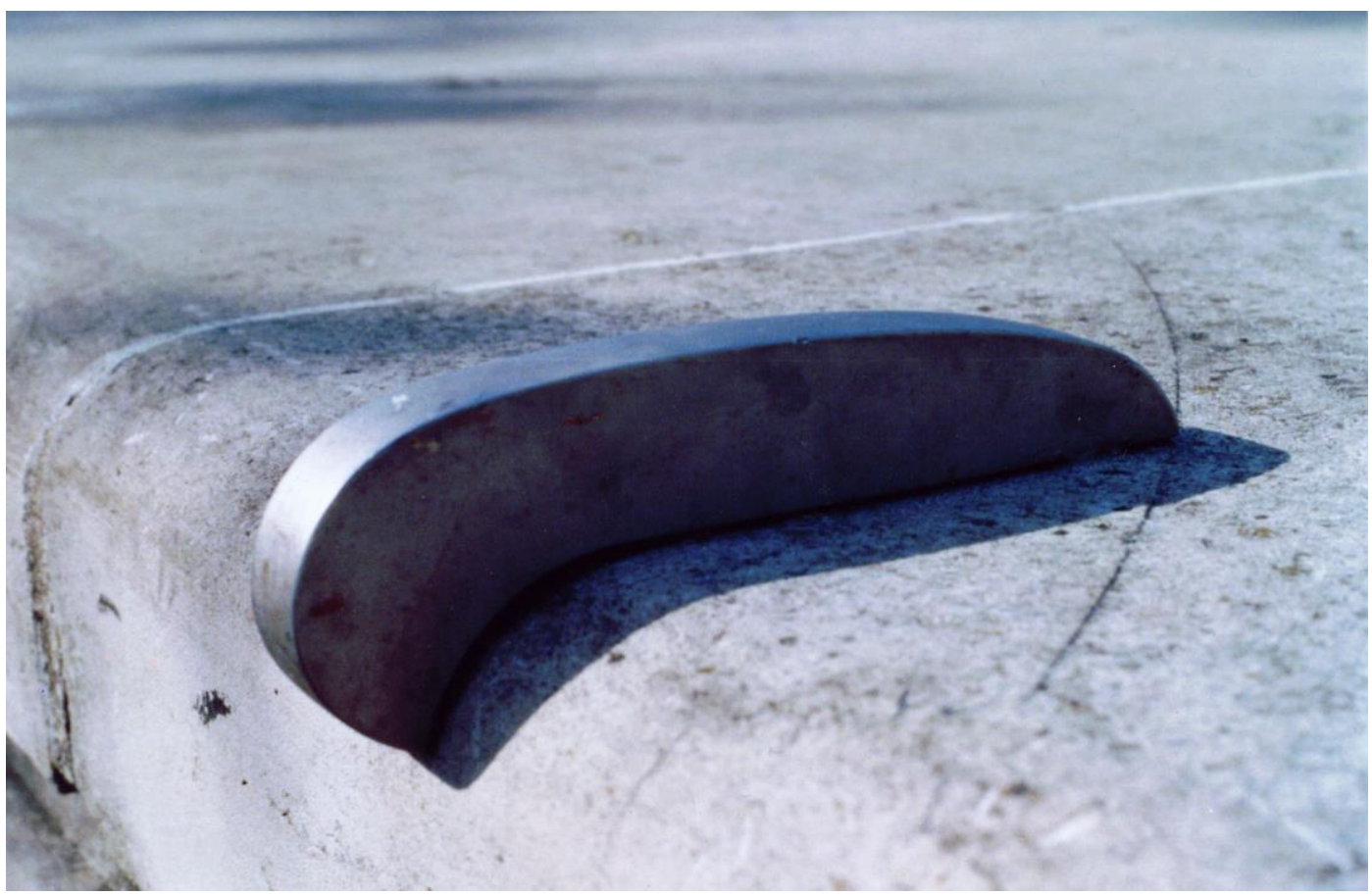

Figure 10: Pig Ears on Public Surfaces 


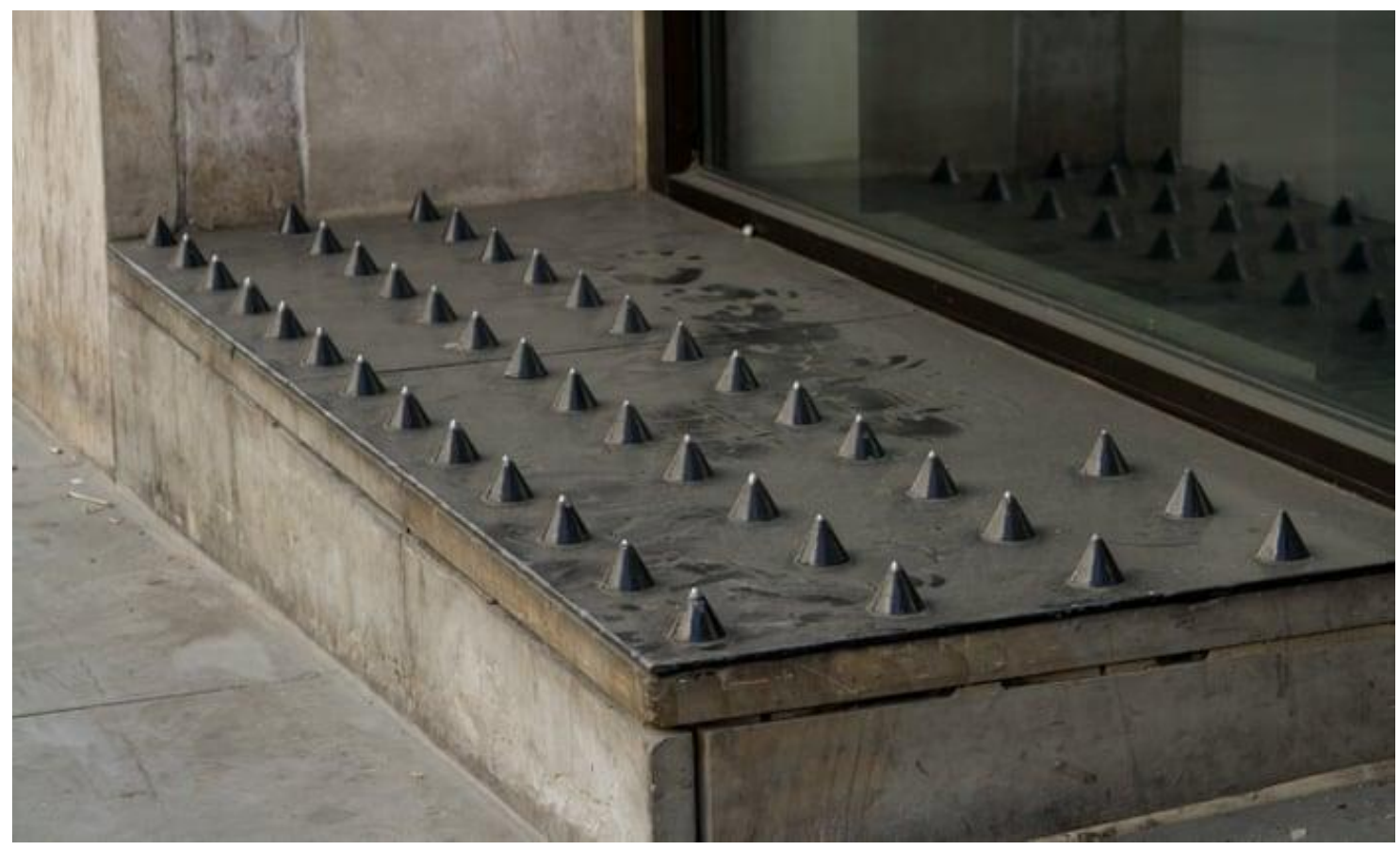

Figure 11: Small Scale ‘Anti-Homeless' Spikes

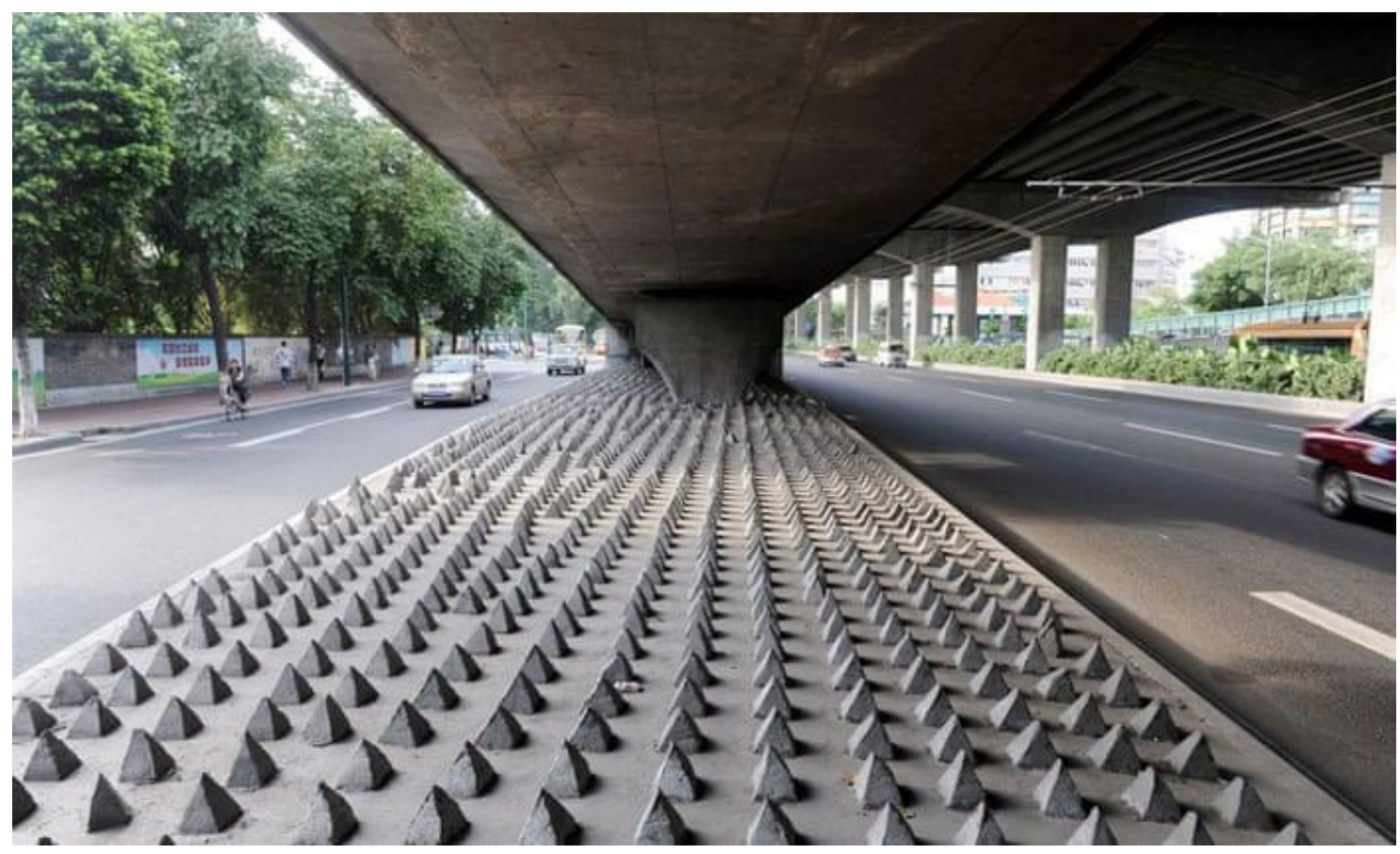

Figure 12: Large Scale ‘Anti-Homeless’ Spikes 


\section{$\underline{\text { Works Cited }}$}

Andreou, Alex. “Anti-Homeless Spikes: 'Sleeping Rough Opened by Eyes to the City’s Barbed Cruelty."' The Guardian, February 18, 2015.

https://www.theguardian.com/society/2015/feb/18/defensive-architecture-keeps-povertyundeen-and-makes-us-more-hostile.

Caluya, Gilbert. "The Post-Panoptic Society? Reassessing Foucault in Surveillance Studies."

Social Identities 16, no. 5 (September 2010): 621-33.

https://doi.org/10.1080/13504630.2010.509565.

“Camden_asb_resistant_bench_apr_2011.Pdf," n.d.

Clarke, Ronald V. “THE THEORY OF CRIME PREVENTION THROUGH ENVIRONMENTAL DESIGN," n.d., 20.

Cornish, Derek B, and Ronald V Clarke. “OPPORTUNITIES, PRECIPITATORS AND CRIMINAL DECISIONS: A REPLY TO WORTLEY'S CRITIQUE OF SITUATIONAL CRIME PREVENTION,” n.d., 56.

Cozens, Paul, and Terence Love. "The Dark Side of Crime Prevention Through Environmental Design (CPTED).” In Oxford Research Encyclopedia of Criminology and Criminal Justice, by Paul Cozens and Terence Love. Oxford University Press, 2017. https://doi.org/10.1093/acrefore/9780190264079.013.2.

Cozens, Paul, Greg Saville, and David Hillier. “Crime Prevention Through Environmental Design (CPTED): A Review Nd Modern Bibliography.” Property Management 23 (December 1, 2005): 328-56.

Crowe, Timothy. Crime Prevention Through Environmental Design: Applications of Architectural Design and Space Management Concepts. Butterworth-Heinemann, 1991. 
De Fine Licht, Karl Persson. "Hostile Urban Architecture: A Critical Discussion of the Seemingly Offensive Art of Keeping People Away.” Etikk i Praksis - Nordic Journal of Applied Ethics 11, no. 2 (November 14, 2017): 27. https://doi.org/10.5324/eip.v11i2.2052.

Design, Unpleasant. Interview with Factory Furniture Design Team: On Benefits of Unpleasant Design, n.d. http://unpleasant.pravi.me/interview-with-factory-furniture-design-team/. Donnelly, Patrick G. "Newman, Oscar: Defensible Space Theory.” In Encyclopedia of Criminological Theory, by Francis Cullen and Pamela Wilcox. 2455 Teller Road, Thousand Oaks California 91320 United States: SAGE Publications, Inc., 2010. https://doi.org/10.4135/9781412959193.n185.

Ferrell, Jeff. "Remapping the City: Public Identity, Cultural Space, and Social Justice." Routledge, 2016.

Hall, Cason Leafe. "No Crime by Design? Crime Deterrence and Urban Design Reform in the USA after World War II," n.d., 97.

Jeffery, C. “Criminology as an Interdisciplinary Behavioral Science.” March 7, 200616 (n.d.). Jeffery, C R, and D L Zahm. “Crime Prevention Through Environmental Design, Opportunity Theory, and Rational Choice Models (From Routine Activity and Rational Choice." Advances in Criminological Theory 5 (1993): 323-50.

Jennings, Wesley. The Encyclopedia of Crime and Punishment. Chichester, West Sussex, UK : John Wiley \& Sons, Boston, Massachusetts, n.d.

Jusiewicz, David Joseph. "CRIME PREVENTION THROUGH ENVIRONMENTAL DESIGN: CRIME FREE MULTI-HOUSING IN ARLINGTON, TEXAS,” n.d., 71. Newman, Oscar. “Creating Defensible Space,” n.d., 126. 
Parnaby, Patrick. "Crime Prevention through Environmental Design: Discourses of Risk, Social Control, and a Neo-Liberal Context" 48 (January 2006).

Paulsen, Derek. Spatial Aspects of Crime. Pearson/Allyn and Bacon, 2004.

Struthers, Kristen. "Why the City Bench Is the Unsung Hero of Good Public Spaces." Nadi (blog), April 8, 2019. https://insights.nadi.design/why-the-city-bench-is-the-unsung-hero-of-good-design.

Swain, Frank. "Designing the Perfect Anti-Object.” Medium (blog), December 5, 2013. https://medium.com/futures-exchange/designing-the-perfect-anti-object-49a184a6667a. 